\title{
地域総合開発におけるマルチプロジェクトプランニング 実施に関する数理計画的アプローチ
}

\author{
春名攻, 竹 林 幹 雄**
}

\section{1.はじめに}

人口の分散定住・産業の分散立地による地方の社会経済振興策は, 地方分権化の流れの中でいくつか の新しい開発政策として実施されつつある。

一般的に，地方の小都市は財政規模も小さく社会経済的な集積も充分ではない状態である。こういっ た地域において，都市化を進行させるためには，まずその都市生活を支える基盤整備の充実が急務であ る。地方部での急速な基盤整備事業の促進するためには, 数多くのプロジェクトの実施を必要とする。こ のため, 地方小都市のように財政的な弱さが顕著な場合は, 都市開発プロジェクトの実施まで自らの手 が回らないのが通常である。したがって, 県や公共機関, 民間企業などによって構成される第 3 セクター を組織し，開発事業推進を図る場合が多い。ところが，社会経済集積のあまりない地域では，大手企業 が自主的に進出してくるといった期待は薄く，第 3 セクター組織などが地域開発を進める中で，望まし い企業を誘致してプロジェクトを成功に導く努力をしなければならない場合が相当数に上ると考えられ る。

本研究では, 上述のような地方の小都市において総合的な都市開発を進めるに当たって, 基盤整備は 地元自治体あるいは国に任せ，第 3 セクターの開発株式会社が公的資金や民間資金を使って開発事業を 進める場合を取り上げることとした。そして, 都市開発事業の経営に過度の負担がかかりすぎ, 経営破 綻に陥らないように配慮した開発事業計画立案の方法論開発を目指すこととした。このため, 研究対象 としては，「計画されている開発事業の実施に関する条件・要求を満たしつつ, 各年度の借入金の返済が 可能な最短のプロジェクト実施期間を与える開発プロジェクト群の実施スケジュールを求める」という 数理計画問題を取り上げた。この問題は，プロジェクトプランニングにおけるマルチプロジェクトプラ ンニングの問題であるが，これまでは最適解法が開発されてなかったために，余り注目されてこなかっ た問題である。本研究では, 上記計画問題の数学的定式化を示すとともに, その問題の最適解法につい ても新たに検討を加えることとする。

\section{2. 地域計画におけるマルチプロジェクトプランニングに関する検討}

地域開発を考える上で，限られた期間に効果の高いプロジェクト実施を行うためには，そのプロジェ クトの与える実施効果を地域開発計画全体の中で明確に位置づけることが必要であることはいうまでも ない。同時に, そのプロジェクトが確実に実行できるという「プロジェクト実現性の保証」も同時に達 成する必要がある。

従来, 都市・地域開発においては, 単一の事業ないしは同質の事業に対する効果計測・効果予測を行 い, 事業実施効果を検討してきたといえる。例えば, 肥田野ら ${ }^{6)}$ は東京都における道路・鉄道などの交通

* 立命館大学

** 神戸大学 
機関を複合的に利用することを考慮し，複合交通空間の整備による効果計測をへドニック・アプローチ による地価観測から行おうとしたものである。ここでは静的な状態での効果計測を議論しているにとど まり, 地域の発展と効果現出の動的変化を議論することが難しい点が問題点として挙げられよう。一方, 複数の大規模プロジェクトの影響把握を行ったものとしては戸田ら ${ }^{2)}$ の研究がある。ここでは, 近畿圏に おける関西国際空港の開発，六甲アイランドの開発など複数の大規模プロジェクトを対象として，これ らが同時複合的に実施された場合の影響を検討するために，ESRAP という評価計測システムを提案し ている。近畿圈の 11 の大規模プロジェクトに対してこの効果計測を実施しているが, 生活の質など定性 的なのほかにアクセシビリティなど定量的な分析指標も導入することで，総合的な評価システムを提案 している。しかし経済システムを内生化していないため，具体的な地域構造の変化の検討を行うことは システムの構成上困難と考えられる。また，ここでも事業実施スケジュールに関しては，明示的に取り 扱われていない点が事業実現性という点で問題であるといえよう。

以上に挙げた研究では，プロジェクトの害施可能性（確実な実行性）については，特に触れられてい ない。しかし，実際には予算制約など各種制約条件によって，実行が必ずしも保証されない可能性が挙 げられる。

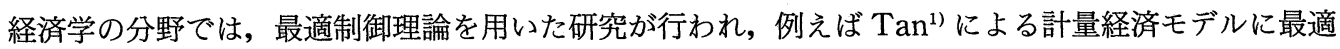

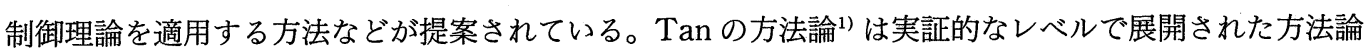
であるが，プロジェクト単位での実行可能性を議論することはモデル構造上難しいと考えられる。

このように,プロジェクト実施効果を最大化すると同時にプロジェクトの確実な実行を前提とすれば, プロジェクト単位の実施効果の計測・動学的な検討を効率的に行うことが可能で，なおかつ地域経済モ デルなどを柔軟に取り入れることができる方法論の開発が必要であると考えられる。これは，少数の小 規模プロジェクト群で全体の整備計画が構成されている場合はそれほど深刻な問題にはならないが，大 規模プロジェクトが複数存在する場合などは，個々のプロジェクトの実現する保証は，プロジェクトの 組み合わせや実施スケジュールによって大きく左右されることになる。特に，財政規模の弱小な地方小 都市では, プロジェクト実施にかかる費用の返済が非常に厳格な制約事項となると考えられる。これは, 効率的な組み合わせ，および実施順序を決定できなければ計画そのものが破綻をきたすというリスクを はらんでいるためである。

本研究では,ともすれば非常にハイリスクになるプロジェクト群によって構成される地域開発計画を, 複数プロジェクトの実施問題という側面から捉え, この実行スケジュールを求めるという意味で「マル チプロジェクトプランニング」問題として問題の整理を行う。

\section{3. マルチプロジェクトにおける最適スケジュール導出に関する検討}

\section{1 概 要}

ここでは，地域開発におけるマルチプロジェクトにおける最適化問題について検討を加える。地域開 発においては，実現目標を「人口」や「産業活動」など多岐にわたる。その全ての実現項目の実現を保 証しながら，なおかつ全体の費用を低減・縮小する，あるいは事業の早期完了を行うといった「複数制 約下における最適化」が要求される。

ここでは事業の早期完了を与える「期間最短問題」に焦点を絞って議論する。まず，プロジェクト全 体に必要な費用, あるいは全体の計画年数は各プロジェクトの実施計画に大きく左右され, 計画全体の 成否はこの実施計画如何によるといえる。さらに，このような大規模なマルチプロジェクト計画の実施 計画に関しては, 問題構造上, 極めて複雑な組み合わせ問題であり, 適切な構造化アプローチを用いる 
ことなしにはNP 困難となる。ゆえに, 従来適切な最適化手法が確立され得なかった。本章では,この 大規模なマルチプロジェクト計画における最適化手法について検討を加え, その解法について近年開発 されたネットワーク型資源配分問題の解法を応用することによる求解法について検討を加えることとす る。

\section{2 定式化}

ここでは，計画主体（ここでは第 3 セクター）が，機能集積をできる限り早期に実現したいと考える 「早期実現型」の計画問題について検討を行う。機能集積が財政規模内で早期に実現されるということは, 当該地域における財政の許容範囲内で地域の活性化を最短時間で実現できるということにつながり, 積 極的な開発投資のスケジュールを考える上で重要な情報となる。

プロジェクトに対する投資を実施する上で，地域計画的には複数の拘束条件が存在する。

1）各年次で目標とされている項目（人口規模, 産業活動, 生活水準など）が計画目標値を達成する こと。

2）各年次において投資額が予算を越えないこと。また投資額は，実質的には借入金からまかなわれ ることを考慮すると，借入金の返済額（あるいは起債額）が予算を超えないこと。

3）計画期間内で必ず目標值が達成できること。

以上のような拘束条件に加えて, プロジェクトには固有の拘束条件が考えられる。

4）各プロジェクトは「先行・後続関係」という実施順序制約を持つ。

5）、各プロジェクトが実行可能になる条件（人口規模, 整備水準など）が存在する。

6）各プロジェクトの実施期間長，および費用は与件である。

さらに，地域の社会経済構造を表現したサブシステムを考慮することにより，プロジェクトの実施に よる地域内の社会経済効果を測定することが可能となる。本研究では, そういったサブシステムを「地 域地域経済シミュレーションモデル」と呼称することとする。本研究でモデル内に内蔵することを想定 しているものは計量経済学に準拠した地域経済モデルである。

マルチプロジェクトプランニング問題においては, 以下のような条件の下に問題の構成が行われる。 以上のような条件の下に，計画の早期実現を目的とした問題の定式化を試みる。

\section{【問題 A】}

〈プロジェクト実施期間最短問題〉

$$
Y\left(\delta_{s}^{i}\right) \rightarrow \text { Minimum }
$$

Sub. to

$$
\begin{gathered}
Z_{i}=\sum_{l} \delta_{l}^{i} X_{l} \text { for all } i \\
z_{i}=\sum_{l} \delta_{l}^{i} x_{l^{\prime}} \text { for all } i \\
\text { if } \delta_{t 1^{\prime}-1}^{i}=0 \cap \delta_{t 1^{\prime}}^{i}=1 \text { and } \delta_{t 2^{\prime}}^{i}=1 \cap \delta_{t 2^{\prime}+1}^{i}=0 \text { then } z_{i}=\sum_{l^{\prime}=t 1^{\prime}}^{t 2^{\prime}} \delta_{l^{\prime}}^{i} x_{l^{\prime}} \text { for all } i \\
M\left(t^{\prime}\right) \geq \sum_{i} \delta_{t^{\prime}}^{i} r_{i}^{t^{\prime \prime}} \\
F_{k}(t) \leq f\left(\delta_{t}^{1}, \cdots, \delta_{t}^{i}, \cdots\right) \text { for all } t \\
W_{j}(t) \geq W_{j}(t-1) \text { for all } j \\
\text { if } \delta_{t}^{i}=1 \cap \delta_{t+1}^{i}=0 \text { then } Q_{k}(t) \geq q_{i k}(k=1,2,3,4)
\end{gathered}
$$




$$
\begin{aligned}
& \text { if } \delta_{t}^{u}=1 \cap \delta_{t}^{v}=1 \text { then } L_{u v}=0 \cap L_{v u}=0 \\
& \text { if } \delta_{t^{\prime}}^{u}=1 \cap \delta_{t^{\prime}}^{v}=1 \text { then } L_{u v}=0 \cap L_{v u}=0
\end{aligned}
$$

ここで,

$\delta_{t}^{i}:$ プロジェクト $i$ が $t$ 年次に実施されていれば 1 , そうでなければ 0 を示すクロネッカーデル夕, $s:$ プロジェクトの開始時期, $Y$ : 総費用, $L:$ プロジェクト実施区間番号, $l^{\prime}$ : 費用返済区間番号, $X_{i}:$ プ ロジェクト実施区間長, $x_{i}$ : 費用返済区間長, $g:$ 利子率, $b:$ 物価上昇率, $C_{i}$ : 現在の物価水準で見積 もったプロジェクト $i$ の総費用, $i$ : プロジェクトを示すインデックス, $Z_{i}:$ プロジェクト $i$ のプロジェ クト年数, $z_{t}$ : プロジェクト $i$ の返済年数, $l^{\prime}$ : 返済区間を示すインデックス, $t^{\prime}$ : 返済年次, $F_{i}(t): t$ 年次における項目 $k$ の整備効果， $f($ ) : 整備効果がプロジェクトの実施によるものであることを示す。 $M\left(t^{\prime}\right): t^{\prime}$ 年次の返済金準備高, $r_{i}^{t^{\prime \prime}}: t^{\prime \prime}$ 年にプロジェクトを開始した場合の単年度返済費用で $r_{i}^{t^{\prime}}=\{(1$ $\left.+g)^{x_{i}}(1+b)^{t^{\prime}} C_{i}\right\} / z_{i}, W_{j}(t): t$ 年度における第 $j$ 産業就業者の分配所得, $k$ : 社会資本整備量の種類, $Q_{k}(t): t$ 年度における社会資本 $k$ の整備量, $q_{i k}$ : プロジェクト $i$ の経営が成立するのに必要な社会資 本 $k$ の整備量, $L_{i_{1}}, L_{i_{2}}$ : 先行可達行列の構成要素である。

ここで $M\left(t^{\prime}\right)$ および $W_{j}(t)$ はサブシステムである地域経済シミュレーションモデルで求められるも のとする。

\section{3 ネットワーク型資源配分問題に関する解法の検討}

まず，本研究で用いる「カット」と「パス」についての概念を簡単に整理する。「カット」とは，プロ ジェクト間の先行・後続関係を示した作業ネットワークについて,「始点から終点までの全てのルートを ただ 1 度切断する」場合に生じる作業集合である。すなわち，カットとはプロジェクトネットワーク上 で同時に実施できるプロジェクトを群として捉えたものである。

図-1 は 7 つのプロジェクトによって構成されたプロジェクトネットワーク（有向グラフ）である。こ こでは，ノード $(0,1,2,3,4)$ がプロジェクトの起終点である。各起終点ごとにプロジェクトの実施順序 が与えられることになる。この順序関係を保持しながら, 同時に実行可能なプロジェクトの集合を「カッ 卜」と呼ぶ。図-1ではカットを $\boldsymbol{C}_{n}$ の形式で，プロジェクトを $[\boldsymbol{k}]$ の形式で示している。例えば， $\boldsymbol{C}_{1}$ は $\{[1],[2],[3]\}$ で構成され， $C_{4}$ は $\{[2],[4],[5],[7]\}$ で構成されることになる。

また「パス」とは以下に示す「カットネットワーク」から求められる, 作業の始点から終点までに至 るカットのつながりを示したものである。

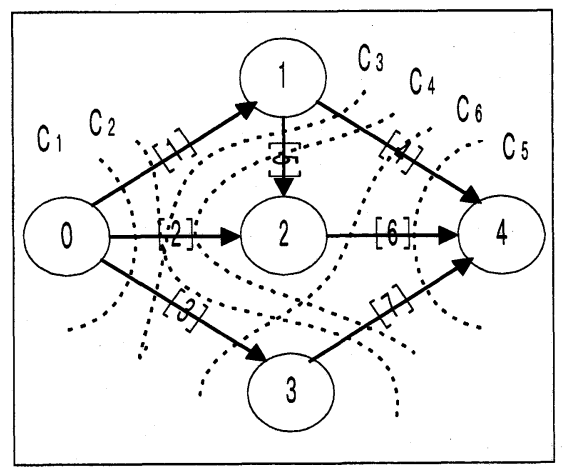

図 1 プロジェクトネットワークとカットの構造

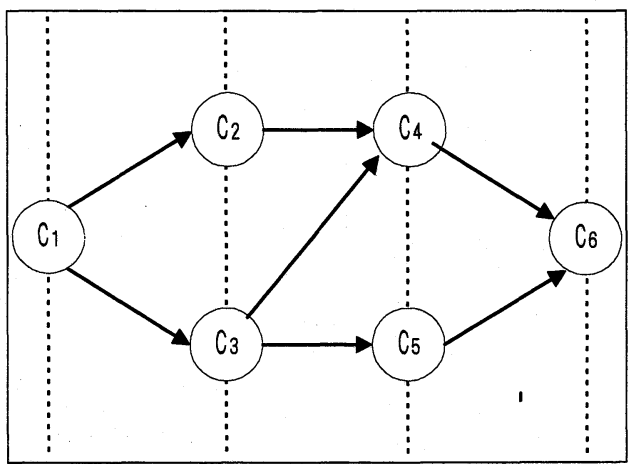

図 2 カットネットワークの形状 
図-2 は図-1 で得られたカットの接続順序別にネットワーク化したもので，「カットネットワーク」と 呼ばれる。このカットネットワークでは, プロジェクトネットワークの実施順序を保持しながら, なお かつ同時に実行できるプロジェクト集合を時間軸上に表現し直したものである。すなわち，プロジェク トネットワークは位相的に等価なカットネットワークに変換できることになる。変換されたカットネッ トワーク上には, 起点カットから終点カットまでに至る複数のパスが存在する。図 -2 では 3 種類の独立 なパスが存在することがわかる。各パスは属する各カットの最短実施時間によって構成される。ゆえに， 最適なプロジェクトの実施順序は, 最適パスを求めることで可能となり, この最適性は最適性の原理に より保証される。

この「カットネットワーク」を用いて，PERT/TIME 型，および PERT-MANPOWER 型の施工計 画問題を解いたものに春名・滑川(4)5) の研究がある。

春名・滑川 ${ }^{445)}$ においては, 複数の施工事業において, 複数の資源制約がある場合のスケジューリング 問題において，カッティング・ストック問題に準拠した解法を提示している。ここでは，DPを用いて最

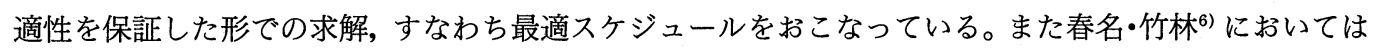
春名・滑川 ${ }^{5)}$ の方法に準拠し, 単年度予算制約を有する方法を用いている。すなわち, 実行可能解の探索 を単年度の実行可能性にまで分解することで，求解を可能にする方法を開発している。

本研究においても，上記 2 種の方法を応用した解法について述べることとする。

今, カットネットワーク上に $n=0,1, \cdots, N$ のレベルをもったカットネットワークがあり, その各ルー トの実施状況を,

$$
R_{n}^{c_{m}}=\left\{r_{n}^{c_{m}}(l)\right\}
$$

という状態変数で表すとする。

ここで, $R_{n}^{C_{m}}$ : 第 $n$ レベルのカットで $n+1$ レベルのカット $C_{m}$ と順序関係を有するカットに属する ルートの状態を示す状態変数, $r_{n}^{C_{m}}(l)$ : 第 $n$ レベルのカットで $n+1$ レベルのカット $C_{m}$ と順序関係を 有するカットに属するルート $l$ の返済年数を表す。

次に決定変数を各レベルのカットへの配分年数とし, これを求める。任意のレベル $n$ で $n+1$ のレベル の $C_{m}$ と順序関係を有するカット $C_{m}^{\prime}$ における状態変数 $R_{n}^{C_{m}}$ のもとでこのカットに配分される年数を $g_{n}^{C_{m}}\left(R_{n}^{C_{m}}\right)$ とする。この值は $C_{m}^{\prime}$ に含まれ、かつ $C_{m}$ に含まれない作業により決定されることとなる。

さらに全てのレベルを通して各ルートの実施計画パターン $\boldsymbol{T R}(\boldsymbol{N})$ を以下のように表す。

$$
\boldsymbol{T R}(\boldsymbol{N})=\left(r^{1}, \cdots, r^{l}, \cdots, r^{L}\right)
$$

ここで, $N$ : カットネットワーク上に存在するレベルの総数, $r^{l}:$ ルート $l$ の実施年数である。

さて対象としている問題では, プロジェクトの前後関係が固定化されているので, 全プロジェクトの 返済スケジュールもカットネットワークの形状に表すことが可能である。また, 全ての返済行為が並列 に実行できる場合は，ただ一つのカットを対象に議論することと同義となる。ただし，この時点ではプ ロジェクトの実施において予算制約を満たした状態であるという保証はない。

本問題は返済の順序関係と実際のプロジェクトの実施の順序関係を構造化した 2 つネットワーク構造 に関する拘束条件を満足させなければならないとともに，任意の時間において，各制約の水準值が変化 (あくまでも非減少) する問題となっている。主問題はプロジェクトの実施順序を表すネットワーク（実 施ネットワーク）に関する最小化問題であるが，同時に返済の順序関係を表すネットワーク（以後, 返 済ネットワークと呼ぶ）の順序関係が存在しているため, 実施カットネットワークのカットは完全な並 
列プロジェクトの集合とはなっていないことがわかる。そして実施状態は, 任意のプロジェクトの実施 終了時点だけではなく, 返済終了時点においても, 各種ストックの増加, 人口増, 税収増など各種項目 の増加によって変化することになる。

前述のとおり本問題では, 実施/返済という 2 つのネットワークが存在する。したがって, 同様に $2 つ$ のカットネットワークが同時に存在することとなる。そして, 全てのプロジェクトを実行可能な状態で 終了させるためには，2つのカットネットワークのすべてのレベルを矛盾なく終点まで進めていくこと が必要である。

任意の時間におけるスケジュール計算において,この時間区間において実施できるプロジェクトは,現 在位置している両カットネットワークの双方のカットに同時に含まれたプロジェクトのみである(なお， 現在のスケジュール計算を行なっている実施/返済の各カットネットワークにおけるカットは,プロジェ クトの配分状態によって容易に確定することができる)。すなわち, 実施カットネットワークを $\boldsymbol{C}_{\boldsymbol{m}}$, 返 済ネットワークのカットを $\boldsymbol{C}^{\prime}{ }_{\boldsymbol{m}^{\prime}}$ とすれば, 現在, 配分できるプロジェクト $i$ は,

$$
i \in \boldsymbol{C}^{\prime}{ }_{\boldsymbol{m}^{\prime}} \cap i \in \boldsymbol{C}_{\boldsymbol{m}^{\prime}+1}
$$

となるプロジェクトのみである。さらに，上記のようなプロジェクトに対して，次のような分類を行な う。すなわち, 実施カットネットワークの現在カットを前記同様 $\boldsymbol{C}_{\boldsymbol{m}}$, このカット $\boldsymbol{C}_{\boldsymbol{m}}$ と順序関係をも次 のベクトルのカットを $\boldsymbol{C}_{\boldsymbol{m}+1}$ とすれば,

$$
i \in \boldsymbol{C}_{\boldsymbol{m}} \cap i \notin \boldsymbol{C}_{\boldsymbol{m}+1}
$$

となるプロジェクトとそれ以外のプロジェクトに分ける。前者のプロジェクトは, 現在のカット区間で 確実に終了させなければならないプロジェクトであり，このことは，このようなプロジェクトの終了時 間が現在カット区間の終了時間を決定することを意味する。すなわち全体の最適時間配分問題における 任意のレベルにおける決定関数值（任意のカット区間長）は，この前者のプロジェクトの最小終了時間 問題を解くことにより求められることとなる。ここではまず, 式 (14) を満足するようなプロジェクトを 対象として, 以下のような処理を加える。

始めにプロジェクトすべてが既に開始されているかをチェックする。さらに開始されているプロジェ クトが既に終了しているかについても調べ, 開始され終了されなければ，無条件に現在実施されている ことになる。すなわち, $\delta_{i}^{t^{\prime}}=1$ とし, 既に終了していれば, $\delta_{i}^{t^{\prime}}=0$ としておく。以上の前処理が終わると, 続いて前処理の段階で返済状態が確定されたプロジェクト以外の式 (13), (14) を満足するプロジェクト を対象として, 以下のような 0-1 整数計画問題を解き, このようなプロジェクトの現在時点における返” 済状態を決定する。

$$
\text { Obj : Maximize } \sum_{i} \delta_{l^{\prime}}^{i}
$$

Sub. to

$$
\sum_{i} \delta_{t^{\prime}}^{i} \gamma_{i}^{t^{\prime \prime}} \leq M^{\prime}\left(t^{\prime}\right)
$$

ここで, $M^{\prime}\left(t^{\prime}\right)$ : 前処理により既に返済が決定しているプロジェクトの返済額を差し引いた返済金準 備高を表す。

さらに, 式 (13) を満足し, 式 (14) を満足していないプロジェクトのうち, 前処理によって返済状態 の決定していないプロジェクトに対して, 次のような 0-1 整数計画問題を解き, 現在時点の返済状態を 決定する。 


$$
\text { Obj: Maximize } M\left(t^{\prime}+1\right)=M\left(\delta_{t^{\prime}}^{i}\right)
$$

Sub. to

$$
\sum_{i} \delta_{t^{\prime}}^{i} \gamma_{i}^{t^{\prime \prime}} \leq M^{\prime \prime}\left(t^{\prime}\right)
$$

ここで, $M^{\prime \prime}\left(t^{\prime}\right):$ 前述までに今期の返済が決定しているプロジェクトの返済分を差し引いた返済金準 備高を表す。

これは，ここでの問題が，プロジェクトの実施状態によって恋化する税収などの都市状態の変化に依 存した条件が非減少であることを仮定しているためである。したがって返済準備高を早期にできる限り 増加させることが, 実施スケジュールの最小化につながることになる。

このようにして，今期の実施／返済パターンが決定したならば，続いてこの同一パターンが連続する 区間長を求めることを考える。このとき，この区間の開始時点は既に決定しているので，実施／返済さ れている任意のプロジェクトのうち,もっとも早く実施あるいは返済が終了するプロジェクトを求め,そ の終了時点を現在区間の区間長とすればよい。しかし，この区間長を決定したプロジェクトの終了時間 が, 返済の終了を表しているか, 実施の終了を表しているか, 等々によって以後の処理が異なってくる こととなる。すなわち, 上述の区間長の決定に際しては, 以下のようなケースが存在する。

a）実施ネットワークにおけるレベル $m$ の現在カットを $\boldsymbol{C}_{\boldsymbol{m}}$ として，このカットと順序関係をもつ レベル $m+1$ のカットを $\boldsymbol{C}_{\boldsymbol{m}+1}$ とすれば，区間長を決定したプロジェクト $i$ が $i \in \boldsymbol{C}_{\boldsymbol{m}} \cap i \notin \boldsymbol{C}_{\boldsymbol{m}+1}$ を満た し, かつ実施終了時間のとき, 実施カットネットワークのカットを $C_{m+1}$ として, 次のレベルの計算を前 述同様進めていく。

b）返済カットネットワークにおけるレベル $m^{\prime}$ のカットを $C^{\prime}{ }_{m^{\prime}}$ として，a）同様レベル $m^{\prime}+1$ の カットを $\boldsymbol{C}_{\boldsymbol{m}^{\prime}+1}$ とすれば, 区間長を決定したプロジェクトが, $i \in \boldsymbol{C}_{\boldsymbol{m}^{\prime}} \cap i \notin \boldsymbol{C}_{\boldsymbol{m}^{\prime}+1}{ }^{\prime}$ を満足し, かつ返済終 了時間のとき, 返済カットネットワークのカットを $\boldsymbol{C}^{{ }^{\prime}{ }^{\prime}+1}$ に進め, 同様のスケジュール計算を繰り返す。

c）それ以外のとき，今期のカットを変化させず，同様のスケジュール計算を進める。

以上のプロセスを矛盾なく最終カットまで行う。このようにして得られたカットネットワークに動的 計画法を適用することで，最適なスケジュール構成が各カットでの作業の合成として表現することが可 能となる。

\section{4. 数 值 計 算}

ここでは，前述のアルゴリズムの有効性を検証するために，数值計算を行う。

\section{1 概 要}

本研究では地方小都市における複数の事業からなる総合開発計画を念頭に置いて, そのうち自治体か ら経営を委託された開発公社（第 3 セクター）が行う事業に焦点を当てて検討対象とし，実施計画を検 討することとする。表-1 は，対象事業の一覧である。

想定されている事業は, 宅地整備事業 4 種, 集客施設整備事業 6 種 (集客施設 $1 \sim 5$, バイパス 1 周辺), 工業用地造成事業 2 種, 道路整備事業 2 種を設定した。用地開発開発事業は全て賃貸を前提としたもの で，売却による一括返済は考慮していない。ゆえに，開発によって必ず一定期間の返済期間をもつこと になる。

本研究では返済パターンを与件とし，毎年次の税収から配分される投資割合を固定值として，全ての 
表 1 想定事業一覧

\begin{tabular}{|c|c|c|}
\hline 事業名 & 事業期間(年) & 先行事業 \\
\hline 工業用地整備 1 & 3 & バイパス2 \\
\hline \multirow[t]{2}{*}{ 集客施設 1} & 1 & バイパス1 \\
\hline & & バイパス2 \\
\hline 工業用地整備 2 & 1 & 宅地整備 1 \\
\hline 集客施設 2 & 1 (3ケ月) & $\begin{array}{c}\text { 工業用地整備 2, } \\
\text { バイパスス周辺 }\end{array}$ \\
\hline 集客施設 3 & 2 & バイパス2 \\
\hline 集客施設 4 & 1 & $\begin{array}{c}\text { 工業用地整備 2, } \\
\text { バイパスス周辺 }\end{array}$ \\
\hline 集客施設 5 & 1 & なし \\
\hline 宅地整備 1 & 2 & バイパス1 \\
\hline 宅地整備 2 & $2-3$ & 宅地整備 1 \\
\hline 宅地整備 3 & 3 & 工業用地整備 1 \\
\hline 宅地整備 4 & 3-5 & 工業用地整備 1 \\
\hline バイパス周辺 & 2 & バイパス1 \\
\hline バイパス1 & 5 & なし \\
\hline バイパス2 & 4 & なし \\
\hline
\end{tabular}

事業が完了する最短時間を求めることとする。このとき，事業費を元本・利子を含めて定額返済する「元 利償還」を採用し, 返済に関しては, 事業の開始時から支払いを開始するものとし（事業期間中も支払 いを行う)利子は $3 \%$ とした。また物価上昇分に関しては年率 $0.5 \%$ で物価が上昇するものと設定してい る。初期人口は 13,000 人とした。

各事業に関する計画初年度での全事業費を表-2に示す。ただし,ここに示した事業費に関する値は, 開 発諸データより設定した仮想的なものであることを断っておく。

プロジェクトの進行を示す実施ネットワークは, 政策的に様々なものが考えられるが，ここでは後述 する整備シナリオに基づいて設定されたネットワークに関して検討を加える。

ここではまず, 地域の内外との結節性の向上を考え, 幹線道路網の整備を優先し, 面的整備に関して は, 既に集積の進んだ町の中心部より次第に集積の少ない周辺部の開発に移行するという開発シナリオ

表 2 事業費（計画初年度換算）

\begin{tabular}{|c|c|c|c|c|c|c|}
\hline 事業名 & $\begin{array}{c}\text { 返済年数 } \\
\text { (年) }\end{array}$ & $\begin{array}{l}\text { 事業費用 } \\
\text { (基準化) }\end{array}$ & 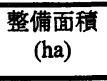 & $\begin{array}{c}\text { 人口增加 } \\
\text { (千人) }\end{array}$ & $\begin{array}{l}\text { 事業実施に } \\
\text { 必要な人口 }\end{array}$ & 返済の先行事業 \\
\hline 工業用地整備 1 & 50 & 200 & 29 & 2.5 & & \\
\hline 集客施設 1 & 10 & 10 & 10 & 0.5 & 18 & \\
\hline 工業用地整備 2 & 10 & 5 & 45 & 1 & & \\
\hline 集客施設 2 & 5 & 5 & 3 & 0.1 & & \\
\hline 集客施設 3 & 5 & 20 & 2 & 2 & & \\
\hline 集客施設 4 & 5 & 3 & 2 & 0.1 & 20 & 集客 3, 集客 4 \\
\hline 集客施設 5 & 20 & 20 & 6 & 0.1 & & 集客 3, 集客 4 \\
\hline $\begin{array}{c}\text { 宅地整備 } 1 \\
\text { (含: 商業施設) }\end{array}$ & 25 & 40 & 143.0 & 5 & & \\
\hline $\begin{array}{c}\text { 宅地整備 } 2 \\
\text { (含:商業施設) }\end{array}$ & 15 & 25 & 78.2 & 1.5 & & \\
\hline 宅地整備 3 & 15 & 27 & 30.1 & 2 & & \\
\hline $\begin{array}{c}\text { 宅地整備 } 4 \\
\text { (含:商業施設) }\end{array}$ & 20 & 30 & 83.7 & 1 & & \\
\hline バイパス1沿線商業 & 15 & 30 & 23.0 & 3 & 15 & \\
\hline バイパス1 & 15 & 100 & 10 & 1 & & \\
\hline バイパス2 & 15 & 80 & 10 & 1 & & \\
\hline
\end{tabular}




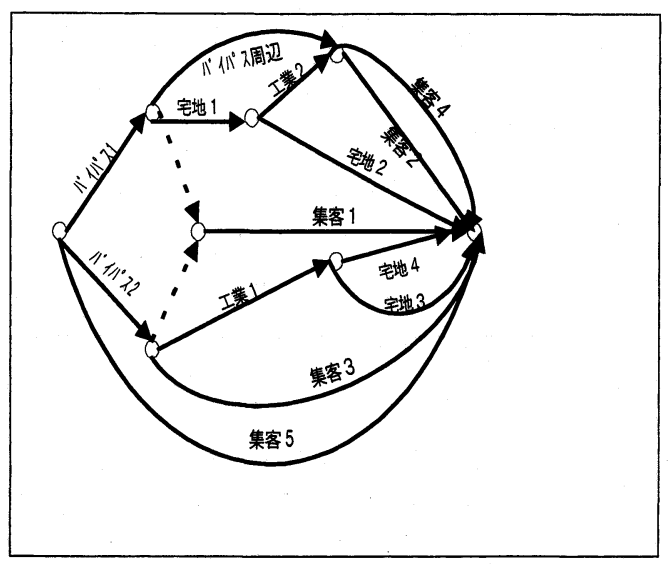

図 3 プロジェクトネットワーク

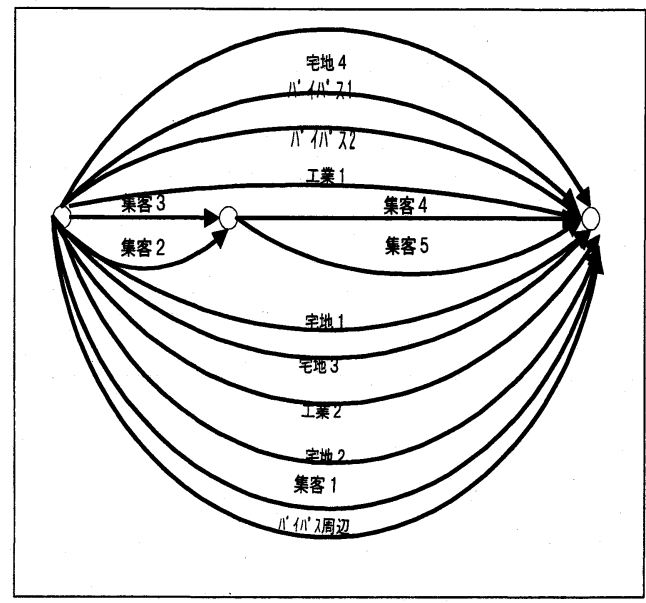

図 4 返済ネットワーク

を想定した上でプロジェクトネットワークを設定した。また，返済に関しては，集客施設のいくつかに 関しては同一の財源から調達するものと考え, 返済の順序を決定した。

さらにここでは前章で示した定式化のうち，プロジェクトが終了する各年次において，想定人口以上 の人口集積を実現しなければならない，という政策上の制約を設けることとした。これは，想定される 人口規模にしたがって各プロジェクトの規模決定がなされているが，この規模決定の妥当性と，想定人 ロの妥当性を検証することも可能とするためである。

また，地域経済への波及効果を計測するためのサブモデルを組み込むことも可能であるが，本稿では まずアルゴリズムの有効性を明らかにすることを第一と考え，表-2に示すように，プロジェクト導入に よる人口増加を事前に固定值として与えることとし，返済準備高金の増額分も人口増加に依存する形と して簡略化した。これにともない，住宅地に関しては商業施設と一体化した整備が多いことと，商業の 生産額は敷地（売り場）面積の他に周辺の居住人口も関係が深いことを考慮し，ひとつの商業ストック として住宅地を扱うこととした。なお，各種ストックについては，簡単な線形関数を仮定し，モデルに 内蔵することとした。

$$
\begin{gathered}
V_{2}=\alpha\left(S_{2}+R R\right) \\
V_{3}=\beta\left(S_{3}+R R\right) \\
W=r(P) \\
M=\varepsilon\left(\eta_{2} V_{2}+\eta_{3} V_{3}+\eta_{0} W\right)=\lambda_{2}\left(S_{2}+R R\right)+\lambda_{3}\left(S_{3}+R R\right)+\lambda_{0} P
\end{gathered}
$$

ここで, $V_{2}: 2$ 次産業の生産額, $S_{2}: 2$ 次産業の累積ストック量, $V_{3}: 3$ 次産業の生産額, $S_{3}: 3$ 次産 業の累積ストック量, $W$ : 家計の平均分配所得, $P$ : 人口, $R R:$ 道路整備累積ストック量, $\alpha, \beta, \gamma:$ 生 産パラメータ, $\eta_{i}$ : 課税率, $\varepsilon$ : 投資配分計数, $\lambda:$ 調整されたパラメー夕を表し, 今回 $\lambda_{2}=0.3, \lambda_{3}=0.3$, $\lambda_{0}=0.6$ と設定して計算を行った。

また，計画目標人口は開始年次より 10 年後に人口 2 万人, 20 年後に 3 万人を達成することを想定し た。なお, 初期設定として人口 $13,000,2$ 次産業ストック 33 ha, 3 次産業ストック 40 ha, 家計の平均分 配所得 500 万円として計算を行った。 


\section{2 計算結果}

前章で述べた最適化手法を用いた結果, 以下のような整備順序, 投資額の推移, 人口増加の推移を得 た。

図-5よりプロジェクトの最短完了をめざした場合, 全プロジェクトは 22 年間で完了することがわか る。このとき, 全返済年数は 64 年間となる。プロジェクトの実行に関しては開始後 11 年目および 16 年 目にピークを迎えることがわかる。ここでは同時に実行可能なプロジェクト数に制限を設けていない。そ こで，同時に実行できるプロジェクト数を隇少させたところ，完了期間に関しては同時実行プロジェク 卜数 4 および 3 では変化せず, 2 の場合は 20 年目に 3 万人を満たす解をえることができなかった。また， 達成目標人口に関しては, 開始後 11 年次初頭以前で 2 万人を達成する解は存在しない。このため設定し た実施条件・返済条件の下では人口 2 万人の実現は 11 年目以前では不可能であることがわかる。

一方，費用の上昇に関しては，プロジェクト数の制約がない場合と比較して，それぞれ 0.04 おび 0.495 の上昇であった。このことから費用の上昇が軽微なことを考えると, 各年次におけるプロジェクト 実施数を少なく押さえても，目標人口の達成は全く同じ期間で可能であるといえる。

返済に関しては以下に示すように，開始後 15〜16 年目に返済額のピークを迎える。この時期と初期の 5 年間が収入と支出がほぼ均衡する形となることが認められる。このため, 初期の予算規模を拡大するこ とができれば，さらに期間は短縮されることが示唆される。本研究では地方自治体からの補助のみを検

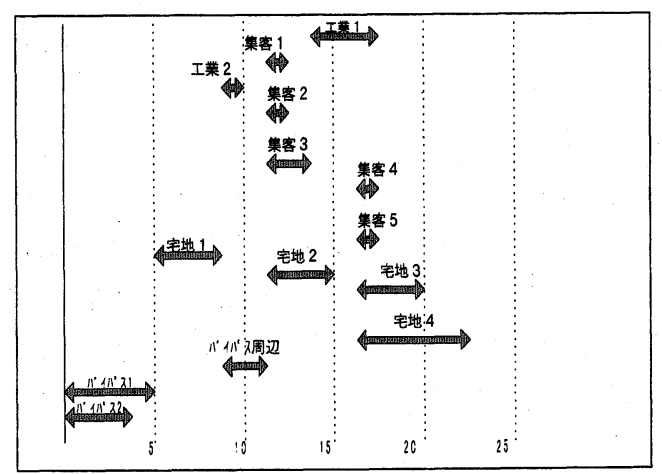

図 5 ・プロジェクトの実施状況

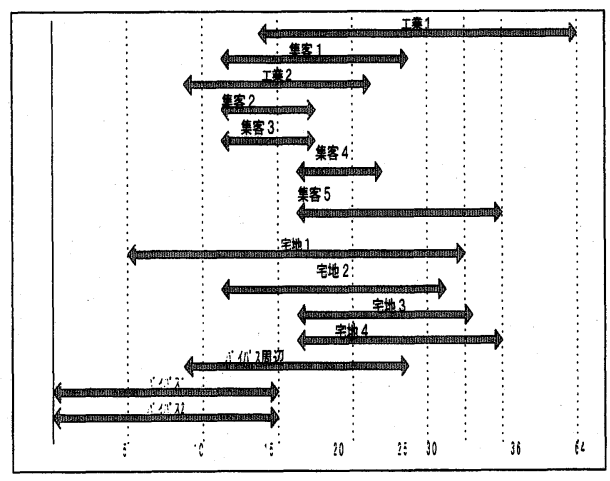

図 6 返済状況

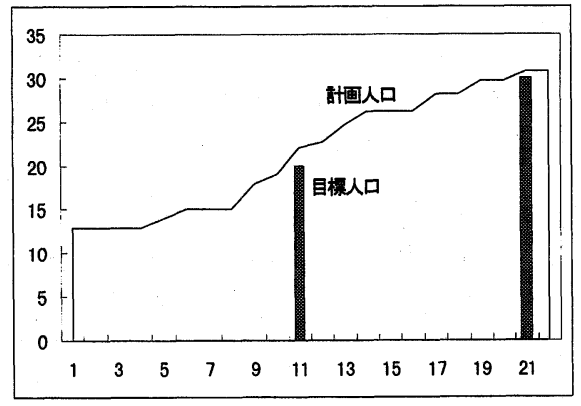

図 7 人口の変遷 


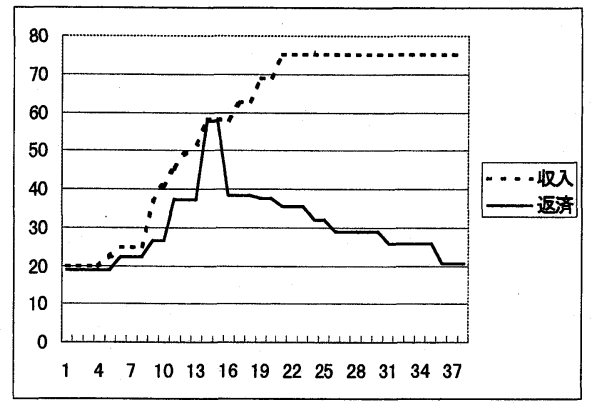

図 8 開発による返済準備高金と返済額の変遷

討対象として取り扱っているので，国からなどの補助金の投入を考える場合，その投入期間の長さ・規 模にスケジュール全体が大きく左右される可能性があることが予想される。

\section{5. おわりに}

本研究では, 地域総合開発をマルチプロジェクトプランニング問題として捉え, プロジェクト実行に 際しての最適スケジューリングを検討する上で，返済に関しても順序関係が存在し，地域経済に関する 制約を付加した場合について検討を加えた。そして，ネットワーク型資源配分問題としての定式化を行 い, 最適スケジュールを求めるための求解アルゴリズムを提示した。さらに, 数值計算により手法の有 効性を検証した。

しかし，本研究で提案したモデルは，以下に挙げる課題を今後検討していく必要がある。

1）投入される各プロジェクトは既知であるが，実際は投入すべきプロジェクトの選択問題を含めた 形で，段階的にアプローチしていく必要があるものと考えられる。

2）事業の実施が全て単年度ごとになっている。本研究では, 3 ケ月などの 1 年に満たない場合, 全て 単年度として計算を行っている。今後は月単位などで, 後続する施工計画との関わりをも検討で きるモデル展開にする必要がある。

3）本研究では, 主として経営的視点に立って検討を加えることとした。このため, 単一目的化する ことで対応することとした。しかし, 実際の計画を行う上では, 複数目的による最適化を検討す ることが必要である。これに対しては, 評価要素に関して本手法を適用し, トレードオフ関係な どを把握する必要があると考えられる。

4）本手法では, 社会的厚生の向上, 例えば開発による環境変化に対する検討など, 数量化すること が難しい検討項目に関しては明示的に取り扱ってはいない。これらの要素に関しては, 計量化す る方法論を検討するとともに，制約条件化して取り込む方法を検討することが必要である。

また, 本研究では直接内蔵しなかった計量経済モデルなどの地域経済モデルを組み込むことは可能で ある。地域経済モデルを内蔵することによりプロジェクト実行による開発効果の予測が詳細に検討する ことが可能となり，本研究の段階で設定した前提条件が緩和されるものと期待できる。これに関しては， 現在開発中であり，機会を改めて発表したいと思う。

\section{参 考 文 献}

[1] Tang, K.C.: Optimal Control of Linear Econometric System with Linear Equality Constraints on the Control Variables, International Economic Review, Vol. 20, 253-258, 1979. 
[2] 戸田常一・天野光三ほか: 大規模プロジェクトによる地域インパクトの計測システム, 土木計画学研 究・講演集, No. 10, 369-376, 1987.

[3] 竹林幹雄・春名 攻: 地域開発プロジェクトにおけるスケジューリングに関する研究, 土木情報シンポ ジウム, 79-86, 1997.

［4] 春名 攻・滑川達ほか: グラフ理論を利用したPERT/MANPOWER 手法の最適解法に関する開発研 究, 土木学会関西支部年次学術講演会概要集, IV-8-1-IV-8-2, 1997.

［5］春名 攻・滑川 達: ネットワーク工程表の構造特性分析と最適工程計画モデル構築に関する理論研 究, 建設マネジメント研究論文集, Vol. 14, pp. 99-pp. 112, 1996.

[6] 肥田野登・武林雅衛: 大都市における複合交通空間整備効果の計測, 土木計画学研究・論文集, No. 8, 121-128, 1990. 


\title{
An Optimal Programming Model for the Multi-Project Planning of the Regional Development
}

\author{
Mamoru HARUNA* and Mikio TAKEBAYASHI**
}

In this paper an optimal programming model is studied for the multi-project planning of the regional development.

Since the regional planning includes various development projects, it is requested for planners to make the multi-project planning being effective and attractive for the regional development.

First, to satisfy this request the model is formulated as the multi-project planning model under such restrictions as the budgeting restriction and the sequential restriction by the predetermined project undergoing and payment returning. There are 2 types of the sequential restriction, project undergoing sequence and payment returning sequence. It is very difficult to solve the optimal solution. However, in this paper, the algorithm that gives the optimal solution under such kind of sequential restriction is presented by the methematical way.

Second, the algorithm to obtain an optimal solution of multi-project planning under the 2 types sequential restriction is developed in the same style as network planning and scheduling algorithm with the resource allocation problem under the resource restriction. The feature of the developed algorithm is,

1) The original network - the project undergoing network and the payment returning network - is divided to the groups that is consisted by the projects that can be undergone at the same time. This is called as "Cuts". The original network can be reformed as the cuts sequence. This is called as "Cuts network".

2) The schedule of projects can be obtained by checking feasibility of each resource allocation step by step using cuts and cuts sequence.

3) Two mathematical tools are used. The optimization in each cut is regarded as the knapsack problem. And the optimization in the cut network is regarded as to find the optimal path in the cut network. This can be solved by using the dynamic programming.

At last, the model developed here is applied to practical regional development project planning problem in which 14 main projects are planned individually and the request to planner is to obtain optimal total schedule of 14 projects. It is confirmed that the model works well to obtain an optimal solution of the targed problem.

\footnotetext{
* Dept. of Civil Engineering, Ritsumeikan University

** Dept. of Civil Engineering, Kobe University
} 